\title{
Effects of biotic and abiotic factors on the health of horse chestnut trees in an urban area of north-western Poland
}

\author{
Magdalena Dzięgielewska $^{1}$, Iwona Adamska ${ }^{2 *}$, Małgorzata Mikiciuk ${ }^{1}$, Grzegorz Nowak ${ }^{3}$, Piotr Ptak ${ }^{1}$
}

West Pomeranian University of Technology, Szczecin, ul. Słowackiego 17, 71-434 Szczecin

${ }^{1}$ Department of Plant Physiology and Biochemistry, ${ }^{2}$ Department of Ecology, Environment Conservation and Management, ${ }^{3}$ Department of Meteorology and Green Areas Management

*e-mail: entomology@zut.edu.pl

Received: 10 July 2017 /Accepted: 27 October 2017

\begin{abstract}
The influence of various damaging biotic and abiotic factors throughout many years have reflected in health status of trees in parks and tree lines. The aim of this research was to reveal the present health status of urban trees in Szczecin with special overview on leaf diseases and insect pests. Research was focused on the most planted tree species: Aesculus hippocastanum and A. $\times$ carnea. The most significant damage caused by pathogenic fungi were in trees infected by Oidium spp. (Erysiphe flexuosa (Peck) U. Braun \& S. Takam) and Phyllosticta paviae Desm. (Guignardia aesculi (Peck) V.B. Stewart). A greater number of fungal species was found at localities near roads (12 taxa) than at those in parks (9 taxa). The greatest influence by insect pests had C. ohridella on horsechestnut trees where a high damage of leaves of over $80 \%$ were observed.
\end{abstract}

Key words: Aesculus spp., parks, tree lines, pathogenic fungi, insect pests, tress health.

\section{Introduction}

The common white horse chestnut (Aesculus hippocastanum L.) is an imposing ornamental tree often seen in town and cities where it is cultivated along park alleys, in municipal gardens and town squares. Decreased health of horse chestnut trees has been observed in Poland over the last two decades. This is related to the spread of the horse chestnut leaf miner Cameraria ohridella Deschka \& Dymić (Lepidoptera: Gracilariidae), which attacks trees leading to the loss of vitality and lower resistance to biotic and abiotic factors (Percival et al., 2011). The insect was first recorded in Europe near the Ohrid lake in Macedonia in 1985 (Wiech, 2003). Fungal pathogens also adversely affect the aesthetic value of horse chestnut trees. Two species in particular can cause widespread epidemics in favourable conditions. Erysiphe flexuosa (Peck) U. Braun
\& S. Takam. (the anamorphic stage of Oidium spp.), which causes powdery mildew, has been recorded in Poland since 2000 (Piątek, 2002; Zimmermannová-Pastirčáková et al., 2002). Guignardia aesculi (Peck) V.B. Stewart (the anamorphic stage of Phyllosticta paviae Desm.; syn. Phyllosticta sphaeropsoidea Ellis \& Everh.), which causes Guignardia blotch of buckeyes and horse chestnut, has been observed in Poland since the 1970s (Madej, 1971a, b).

The aim of this study was to assess the health and condition of horse chestnut trees A. hippocastanum L. and $A$. ×carnea Hayne in relation to site location and co-occurrence of pathogens and the horse chestnut leaf miner C. ohridella. Developmental stages of the trees and foliar content of assimilation pigments in the vegetative season were examined. 


\section{Study area}

Field observations were conducted in the years 20152016 in town greens in the city of Szczecin. A total of ten transects with the European white horse chestnut $A$. hippocastanum L. and the red horse chestnut $A$. × carnea growing at localities along roads and in parks were examined. Trees at these sites were monitored mid-month between June and September each year.

Horse chestnut trees growing at different sites were selected for analysis to reflect conditions both favourable (park localities) and unfavourable (localities along roads) for their growth and development. Typical phenological events were selected based on the literature (Krotoska, 1961; Bielawska et al., 1964; Chylarecki \& Straus, 1968; Stachak, 1968, 1977; Łukasiewicz, 1984; Nowak, 2000) and on the individual development of the trees. Tree height (Silva tree height measurer) $\pm 0.5 \mathrm{~m}$, tree trunk diameter (at $130 \mathrm{~cm}$ ) $\pm 1 \mathrm{~cm}$ and crown diameter were measured during phenological observations. Localities are described in Table 1.

\section{Material and methods}

The frequency of pathogens and pests (tree disease) was assessed based on the percentage contribution of leaves with symptoms of mining by pests or colonization by fungi in the tree crown in relation to the entire crown. Both values were estimated independently from each other. Results for trees at one locality were averaged.

The leaf surface infected by insects and pathogens was based on the percentage contribution of the leaf surface with damage symptoms in relation to the entire surface of the leaf lamina. The size was estimated individually for each of the two criteria (damage by insects and infection by pathogens) for 20 leaves selected randomly from the lower part of the tree crown and the results were averaged. Moth emergence was monitored in the Kasprowicz Park (B3 transect, Table 1) based on the number of males caught in delta pheromone traps suspended on the branches of white horse chestnut trees at $3 \mathrm{~m}$ above the soil (one trap in locality). Pheromone dispensers in the traps were changed every four weeks and adhesive bottom tapes were changed every week during inspections. Moth emergence was observed between April and October 2016.

Leaf sections exhibiting visible tissue discolouration (leaf blotch), mycelium coating, spore agglomerations and fungal fruitbodies were considered to be colonized by pathogens. Leaves were examined for the occurrence of the mycelium, oidia and cleistotecia in the case of Erysiphe flexuosa and for the occurrence of leaf blotches and picnidia with spores in the case of Guignardia blotch of horse chestnut. The species composition of fungi was analyzed in laboratory conditions directly after collection of the plant materials based on the percentage contribution of leaves with symptoms of diseases. The nomenclature of fungi is given after the Index Fungorum (www.indexfungorum.org; last accessed 14.01.2017).

The content of photosynthetic pigments in leaves, damage caused by insects and infection with pathogens were studied in the growing season in different localities (along streets and in parks). The foliar content of chlorophyll $\mathrm{a}$ and $\mathrm{b}$ and total chlorophyll using the method by Arnon et al. (1956) as modified by Lichtenthaler and Wellburn (1983) and the content of carotenoids using the method by Hager and Mayer-Berthenrath (1966) were determined in physiological examinations. Foliar extracts of assimilation pigments were obtained by crushing samples of fresh mass, ca. $0.05 \mathrm{~g}$, in a mortar using $10 \mathrm{~cm}^{3} 80 \%$ acetone. Homogenates were centrifuged for $10 \mathrm{~min}$. at 1500 rates per minute. Optical density of samples was determined spectrophotometrically at wavelengths $\lambda=440,645$ and $663 \mathrm{~nm}$. Pigment content was determined in four replicates and expressed in $\mathrm{mg} \cdot \mathrm{g}^{-1} \mathrm{f} . \mathrm{m}$. of the plant. These determinations could not be performed at locality A2 in September 2016 as the physiological condition of the leaves of the white horse chestnuts was very poor.

A one-way analysis of variance (experimental unit locality) and a comparison of averages using the Duncan test, significance level 0.05 , were carried out to statistically analyse the content of assimilation pigments in the leaves of white horse chestnut trees growing at different localities. A one-way analysis of variance (experimental unit - horse chestnut species) was conducted to compare pigment content in the leaves of two species of horse chestnuts growing along roads and in parks.

\section{Results and discussion}

The condition of horse chestnut trees can be adversely affected by a range of factors, both biotic (insects, fungi) and abiotic such as low temperatures, water deficits, high substrate salinity and traffic pollution (Baranowski et al., 2002). The results of our studies show that the drying and premature (as early as in mid-August) leaf fall of horse chestnut trees growing in plantings along roads are affected not only by infestations of the horse chestnut leaf miner but also by the above abiotic factors and pathogenic fungi. Horse chestnut trees growing in urban conditions are exposed to strong anthropopressure. Many biotic factors such as herbivorous insects and pathogenic fungi considerably worsen the condition of these trees. 
Table 1. Description of tree plantings and localities selected for study (dendrological inventory)

\begin{tabular}{|c|c|c|c|c|c|c|c|c|}
\hline No. & $\begin{array}{l}\text { Locality } \\
\text { no }\end{array}$ & Location & Tree species & $\begin{array}{l}\text { Number } \\
\text { of trees } \\
\text { monitored } \\
\text { [individu- } \\
\text { als] }\end{array}$ & $\begin{array}{l}\text { Description } \\
\text { of locality }\end{array}$ & $\begin{array}{l}\text { Range of tree } \\
\text { trunk diameter } \\
{[\mathrm{cm}] \text { at } 130 \mathrm{~cm}} \\
\text { above the soil }\end{array}$ & $\begin{array}{l}\text { Height } \\
\text { range } \\
{[\mathrm{m}]}\end{array}$ & $\begin{array}{c}\text { Range } \\
\text { of crown } \\
\text { diameter } \\
{[\mathrm{m}]}\end{array}$ \\
\hline \multicolumn{9}{|c|}{ A - LOCALITIES ALONG ROADS } \\
\hline 1 & A1.1 & \multirow[t]{2}{*}{$\begin{array}{c}\text { St. } \\
\text { Narutowicza }\end{array}$} & $\begin{array}{c}\text { Aesculus } \\
\text { hippocastanum }\end{array}$ & 10 & $\begin{array}{l}\text { Trees grow } \\
\text { along the central } \\
\text { reservation on a dual } \\
\text { carriageway } 10-15 \mathrm{~m} \\
\text { wide; surface - lawn }\end{array}$ & $155-200$ & $13-16$ & $7-10$ \\
\hline 2 & A1.2 & & $\begin{array}{l}\text { Aesculus } \\
\times \text { carnea }\end{array}$ & 10 & $\begin{array}{l}\text { Trees grow } \\
\text { along the central } \\
\text { reservation on a dual } \\
\text { carriageway } 10-15 \mathrm{~m} \\
\text { wide; surface - lawn }\end{array}$ & $16-23$ & $3-4$ & $1-3$ \\
\hline 3 & A2 (A3) & $\begin{array}{l}\text { Av. Wojska } \\
\text { Polskiego }\end{array}$ & $\begin{array}{c}\text { Aesculus } \\
\text { hippocastanum }\end{array}$ & 10 & $\begin{array}{l}\text { Trees grow on a lawn } \\
\text { bordered by the } \\
\text { pavement on one side } \\
14-16 \mathrm{~m} \text { from the } \\
\text { road }\end{array}$ & $192-252$ & $15-20$ & $9-11$ \\
\hline 4 & A3 (A4) & $\begin{array}{c}\text { St. } \\
\text { Słowackiego }\end{array}$ & $\begin{array}{c}\text { Aesculus } \\
\text { hippocastanum }\end{array}$ & 10 & $\begin{array}{l}\text { Trees grow near } \\
\text { the pavement, soil } \\
\text { surface, hardened }\end{array}$ & $228-310$ & $24-26$ & $9-11$ \\
\hline 5 & A4 (A7) & $\begin{array}{c}\text { St. } \\
\text { Mickiewicza }\end{array}$ & $\begin{array}{c}\text { Aesculus } \\
\text { hippocastanum }\end{array}$ & 10 & $\begin{array}{l}\text { Trees grow in tree } \\
\text { pits }\end{array}$ & $217-240$ & $18-20$ & $9-11$ \\
\hline \multicolumn{9}{|c|}{ B - LOCALITIES IN PARKS } \\
\hline 6 & B1 & Kownas Park & $\begin{array}{l}\text { Aesculus } \\
\times \text { carnea }\end{array}$ & 6 & $\begin{array}{c}\text { Trees grow on the } \\
\text { lawn surface }\end{array}$ & $205-310$ & $20-22$ & $8-10$ \\
\hline 7 & B2 & & $\begin{array}{c}\text { Aesculus } \\
\text { hippocastanum }\end{array}$ & 6 & $\begin{array}{l}\text { Trees grow on the } \\
\text { parks' surface; } \\
\text { control locality - } \\
\text { no maintenance } \\
\text { measures, including } \\
\text { leaf removal }\end{array}$ & $\begin{array}{c}226 \text { at } 60 \mathrm{~cm} \text {, } \\
\text { two trunks } \\
\text { above, } 141 \text { and } \\
144\end{array}$ & $16-18$ & $7-9$ \\
\hline 8 & B3 & $\begin{array}{l}\text { Kasprowicz } \\
\text { Park }\end{array}$ & $\begin{array}{c}\text { Aesculus } \\
\text { hippocastanum }\end{array}$ & 10 & $\begin{array}{c}\text { Trees grow on lawn } \\
\text { surface }\end{array}$ & $190-227$ & $19-22$ & $8-12$ \\
\hline 9 & B4 & St. Wilcza & $\begin{array}{c}\text { Aesculus } \\
\text { hippocastanum }\end{array}$ & 10 & $\begin{array}{l}\text { Trees grow on lawn } \\
\text { surface }\end{array}$ & $113-221$ & 19-21 & $7-8$ \\
\hline 10 & B5 & $\begin{array}{l}\text { Central } \\
\text { Cemetery }\end{array}$ & $\begin{array}{c}\text { Aesculus } \\
\text { hippocastanum }\end{array}$ & 10 & $\begin{array}{c}\text { Trees grow near } \\
\text { a road hardened } \\
\text { with asphalt, on soil } \\
\text { surface, hardened }\end{array}$ & $176-229$ & $24-26$ & $7-9$ \\
\hline
\end{tabular}




\subsection{Phenophases of horse chestnut trees}

Differences in the course of phenological events in trees growing at different localities were observed in 2015-206. The vegetation of red horse chestnut trees took place first preceding white horse chestnut trees growing at localities in parks even by up to a week. White horse chestnut trees began to flower in late April and early May while red horse chestnut trees started to flower approximately a week later. The flowering ended in late May and early June. Early foliar discolouration was observed towards the end of $\mathrm{Au}-$ gust (the first strongly infected leaves also began to fall at that time) and peaked in late September and early October which coincided with leaf fall. Leave fall ended at the end of November at all the localities (Table 2).
4.2 The dynamics of the emergence of the horse chestnut leaf miner Cameraria ohridella in the season

Observations of pest development were undertaken when the first generation of moths emerged in late April (24.04) Fig. 1. The emergence of the first-generation moths was spread over time and peaked in mid-June (11.06). The occurrence of the second-generation adult moths was observed in July (Fig. 1). The peak emergence of the summergeneration moths (generation II) was recorded in mid-July (12.07). The emergence of the autumn-generation of moths (generation III) began in August and moth activity peaked in early September (06.09). The number of moths baited in pheromone traps decreased considerably in October (Fig. 1).

A considerable drop by over $50 \%$ in the frequency of moths caught in pheromone traps can be noticed based

Table 2. Mean dates of phenological events in horse chestnut trees at localities near roads and in parks in Szczecin between April and November 2016

\begin{tabular}{|c|c|c|c|c|c|c|c|c|c|}
\hline No. & 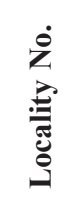 & 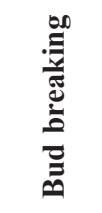 & 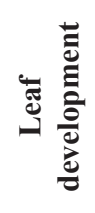 & 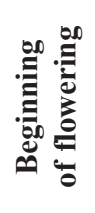 & 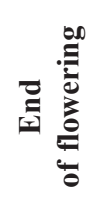 & 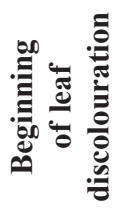 & 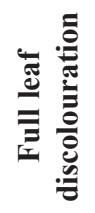 & 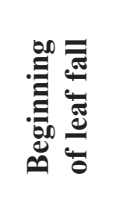 & 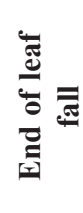 \\
\hline \multicolumn{10}{|c|}{ A - Localities along roads } \\
\hline 1 & A1.1 & 11.04 & 24.04 & 29.04 & 30.05 & 04.09 & 03.10 & $\begin{array}{c}(22.08) \\
01.10\end{array}$ & 04.11 \\
\hline 2 & A 1.2 & 08.04 & 20.04 & 06.05 & 30.05 & 18.09 & 03.10 & $\begin{array}{c}(22.08) \\
07.10\end{array}$ & 04.11 \\
\hline 3 & $\mathrm{~A} 2$ & 13.04 & 24.04 & 02.05 & 28.05 & 27.08 & 28.09 & $\begin{array}{c}(22.08) \\
01.10\end{array}$ & 04.11 \\
\hline 4 & A3 & 13.04 & 22.04 & 27.04 & 28.05 & 27.08 & 30.09 & $\begin{array}{c}(22.08) \\
01.10\end{array}$ & 04.11 \\
\hline 5 & A4 & 11.04 & 22.04 & 02.05 & 28.05 & 27.08 & 28.09 & $\begin{array}{c}(22.08) \\
01.10\end{array}$ & 04.11 \\
\hline \multicolumn{10}{|c|}{$\mathrm{B}-$ localities in parks } \\
\hline 6 & B1 & 06.04 & 24.04 & 08.05 & 30.05 & 22.09 & 03.10 & $\begin{array}{c}(27.08) \\
07.10\end{array}$ & 04.11 \\
\hline 7 & B2 & 13.04 & 20.04 & 05.05 & 03.06 & 27.08 & 30.09 & $\begin{array}{c}(27.08) \\
07.10\end{array}$ & 04.11 \\
\hline 8 & B3 & 16.04 & 24.04 & 02.05 & 30.05 & 10.09 & 03.10 & $\begin{array}{c}(27.08) \\
07.10\end{array}$ & 04.11 \\
\hline 9 & B4 & 16.04 & 24.04 & 02.05 & 30.05 & 10.09 & 03.10 & $\begin{array}{c}(27.08) \\
07.10\end{array}$ & 04.11 \\
\hline 10 & B5 & 16.04 & 26.04 & 02.05 & 30.05 & 10.09 & 03.10 & $\begin{array}{c}(27.08) \\
07.10\end{array}$ & 04.11 \\
\hline
\end{tabular}




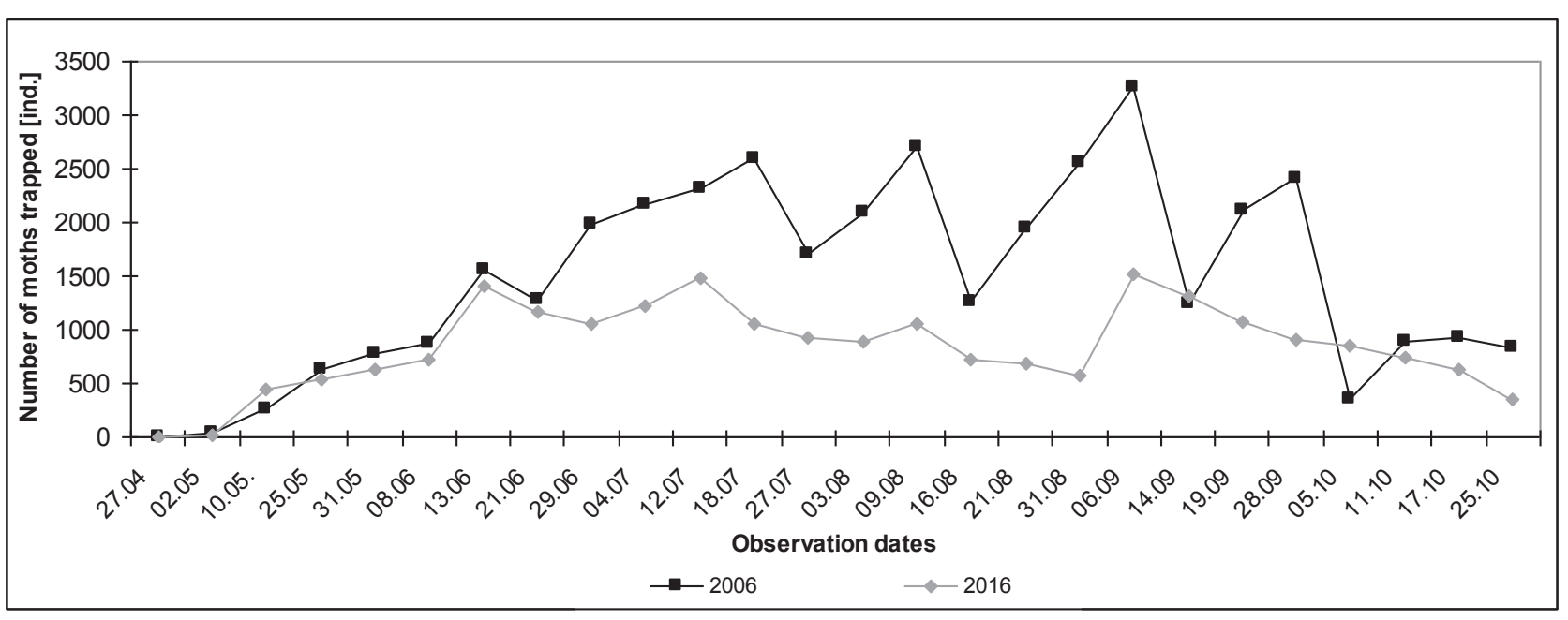

Figure 1. A comparison of the dynamics of the emergence of horse chestnut leaf miner C. ohridella moths in 2006 and 2016 based on the catch of male moths in pheromone traps

on observations of the emergence of the C. orhidella imago conducted from May to October in the last decade (Fig. 1). Literature data show that the peak stage of the invasion has now moved to eastern-Baltic states and Belarus, where the greatest damage to horse chestnut trees may be expected in the near future (Kosibowicz, 2005). The differences can be indicative of greater effectiveness of the environment's natural resistance which is a response to the long-term mass occurrence of the leaf miner on horse chestnut trees. At present, over 30 species of insects infecting different development stages of the horse chestnut leaf miner are known. The majority of them are classified as parasitic Hymenopterans (Grabenweger, 2003). Parasitization of the leaf miner at many localities in Europe ranges between 3\% and 21\% (Grabenweger, 2003; Grabenweger et al., 2005; Girardoz et al., 2006). In Poland, parasitization of the leaf miner was even $50 \%$ at particularly sun-exposed sites (Bystrowski et al., 2008). Insecticidal fungi are another biological factor that limits the vitality of larvae and pupae of the leaf miner; the efficiency of infection of different development stages of the leaf miner ranges from $16 \%$ up to $47 \%$ (Metla et al., 2013).

\subsection{The level of horse chestnut tree infection by Cameraria ohridella, Oidium spp. and Phyllosticta paviae}

The first burrows on the leaves were observed on white horse chestnut trees, A. hippocastanum, in mid-May. Between then and late August the mean number of larvae in the leaves of the trees successively increased and reached 30 caterpillars per leaf in periods of intense feeding. High foliar damage by the leaf miner reaching over
$50 \%$ was recorded at the localities of the white horse chestnut as early as in August and was observed in both trees directly located along transport routes, away from traffic and in park plantings (Fig. 3). Slight differences in the general level of tree infection by the leaf miner at the study sites were noted during seasonal observations: a higher percentage of infected leaves in the tree crown was observed for $A$. hippocastanum individuals growing in dense town greens than that is roadside plantings with A. hippocastanum (Fig. 2). A high damage of over $80 \%$ of the leaf by the miner led to a premature leaf fall as early as in the second half of August and a second flowering of horse chestnut trees in late summer and early September.

Individuals of red horse chestnut trees, $A \times$ carnea, were considerably more resistant to infection by the leaf miner and leaf infection did not exceed $4 \%$ at a roadside locality (A2) and $10 \%$ at a park locality (Fig. 5). A comparable low infection percentage was noted for tree crowns of $A$. $\times$ carnea (Fig. 4). Literature data show that $C$. orhidella infects the leaves of the white horse chestnut $A$. hippocastanum the strongest (Bichta \& Kozakiewicz, 2002). It colonizes both old and young trees, mostly along roads and in urban parks (Zaraś-Januszkiewicz, 2004). It damages the leaves of red buckeye Aesculus pavia, sweet buckeye A.flava and red horse chestnut $A$. × carnea considerably less, and it does not develop in the leaves of Ohio buckeye Aesculus glabra and dwarf buckeye Aesculus parviflora. The leaf miner is also known to infect sycamores Acer pseudoplatanus and maple trees Acer platanoides (ZaraśJanuszkiewicz, 2004).

Microclimatic conditions favourable for the development of the horse chestnut leaf miner were recorded in our study at park localities of both white and red horse chest- 
nut trees. The insect frequency was high in dense plantings. Studies by Bystrowski et al. (2008) show that the leaf miner developing in sun-exposed tree crowns, planted as belts along roads and as individual trees in parks is attacked more frequently by parasitoids.

A decreasing foliar content of assimilation pigments, especially at park localities, reflects the influence of the leaf miner on physiological processes occurring in weakened trees. Long-standing infection by the leaf miner can cause shoot dwarfing, sparse foliage and increased susceptibility to disease (Dudzik, 2002). The disturbed rhythm of tree development often causes decreased resistance to frost and increases susceptibility to disease (Soika, 2004).

Removing fallen leaves is one of the methods used to control the leaf miner. Uncollected leaves are often a source of reinfection the following year. This was observed in the Kasprowicz Park in Szczecin, where leaves of A. hippocastanum were not removed in the autumn during protective treatment and a mass emergence of leaf miner moths in the spring and a high infection degree (80-100\%) were recorded - locality B2 (Figs 2, 3).

Twelfth species of fungi colonizing leaves of horse chestnut trees were identified in our study. The anamorphic and teleomorphic stages of the causal agent of powdery mildew [Oidium spp.] and the anamorphic stage of the fungus causing Guignardia blotch of buckeyes and horse chestnut [Phyllosticta paviae Desm.] were the most frequently noted fungi. Conditions for the development of fungi colonizing horse chestnut trees were better at localities along roads than at those in parks and a greater number of fungal species was found at localities near roads (12 taxa) than at those in parks (9 taxa). A higher degree of infection of the trees (Figs 2, 4) and greater leaf colonization by fungi (Figs 3, 5) were also observed. These values varied for individual pathogens and diseases caused by them.

Powdery mildew occurred on horse chestnut trees at both types of localities (parks and streets). However, differences in the frequency and colonization degree of leaves by the pathogen were noted in both groups (Figs 2-5). A correlation between an increased occurrence of Oidium spp. and the host species was recorded. A. × carnea was found to be less resistant than $A$. hippocastanum. This was observed both at localities along roads and at localities in parks.

Guignardia blotch of horse chestnut symptoms occurred more frequently in trees at localities along transport routes than at localities away from them. The level of infection of leaves by Phyllosticta paviae was also greater at localities along roads than the leaves of trees in parks. Leaf surface with signs of colonization by $P$. paviae was lower than that caused by Oidium spp. at all the localities (Figs 2-5).

Leaves of horse chestnut trees at park locality B2 were colonized only by fungi of the genus Cladosporium. This was related to an early and high damage of laminae by larvae of $C$. ohridella. This locality was not maintained (fallen leaves were not removed) which on the one hand encouraged the occurrence of the leaf miner and on the other hand inhibited the infection of plant tissue by the causal agent of powdery mildew. The fungus Oidium

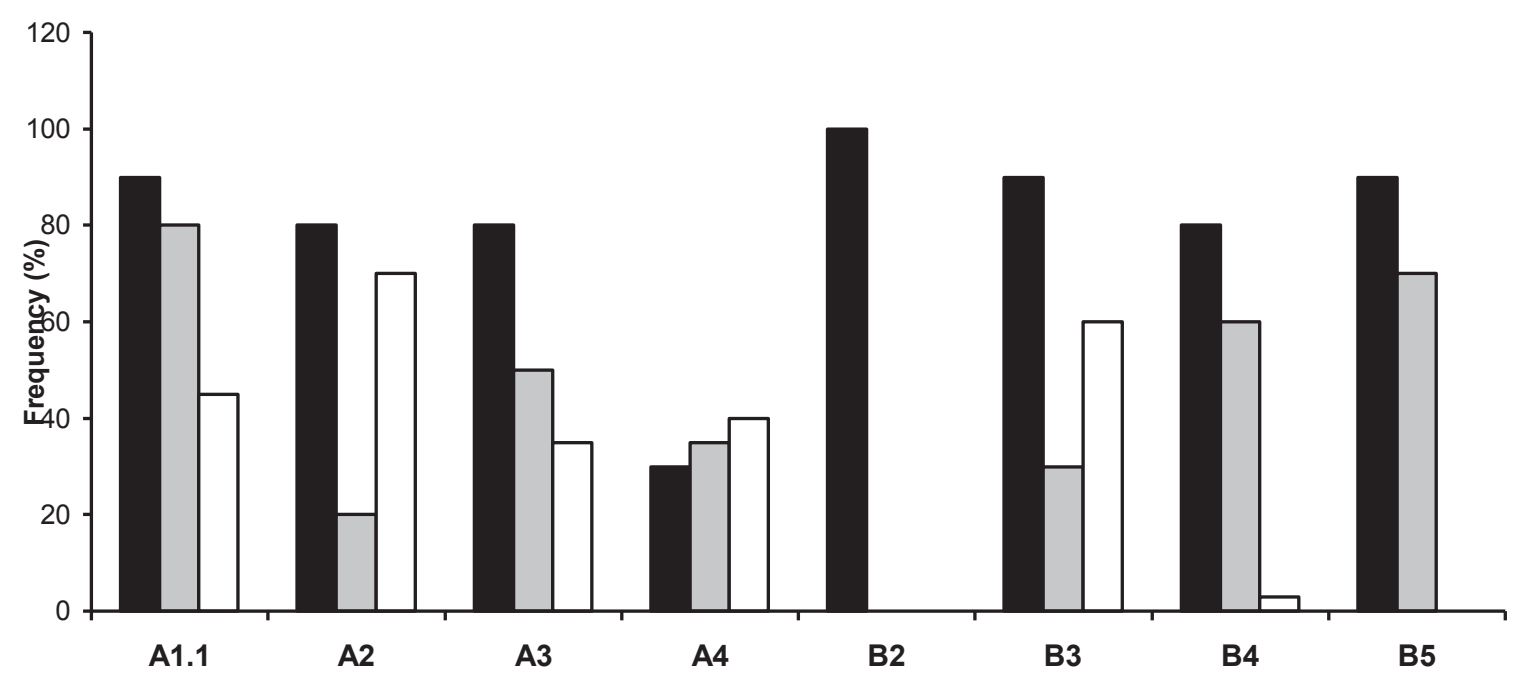

- Cameraria ohridella $\square$ Oidium spp., Erysiphe flexuosa $\square$ Phyllosticta paviae

Figure 2. Maximum frequency values of the pests and pathogens examined in the study (percentage contribution of infected leaves in relations to all the leaves in the crown) at selected localities with white horse chestnut $A$. hippocastanum throughout the vegetative season ( $\mathrm{A}$ - localities along roads, $\mathrm{B}$ - plantings in parks) 
sp. are able to colonize only living plant tissue and can develop on such tissue.

The influence of climatic conditions, and in particular a habitat's microclimate, on plant infection by pathogens and the occurrence of disease symptoms is high (Oszako,
2007; Suchocka, 2011). Humidity conditions in spring are very important for horse chestnut trees (Łukasiewicz \& Oleksyn, 2007). Factors relating to human activity, for instance maintenance measures and land development of areas surrounding the trees that may inhibit a plant's

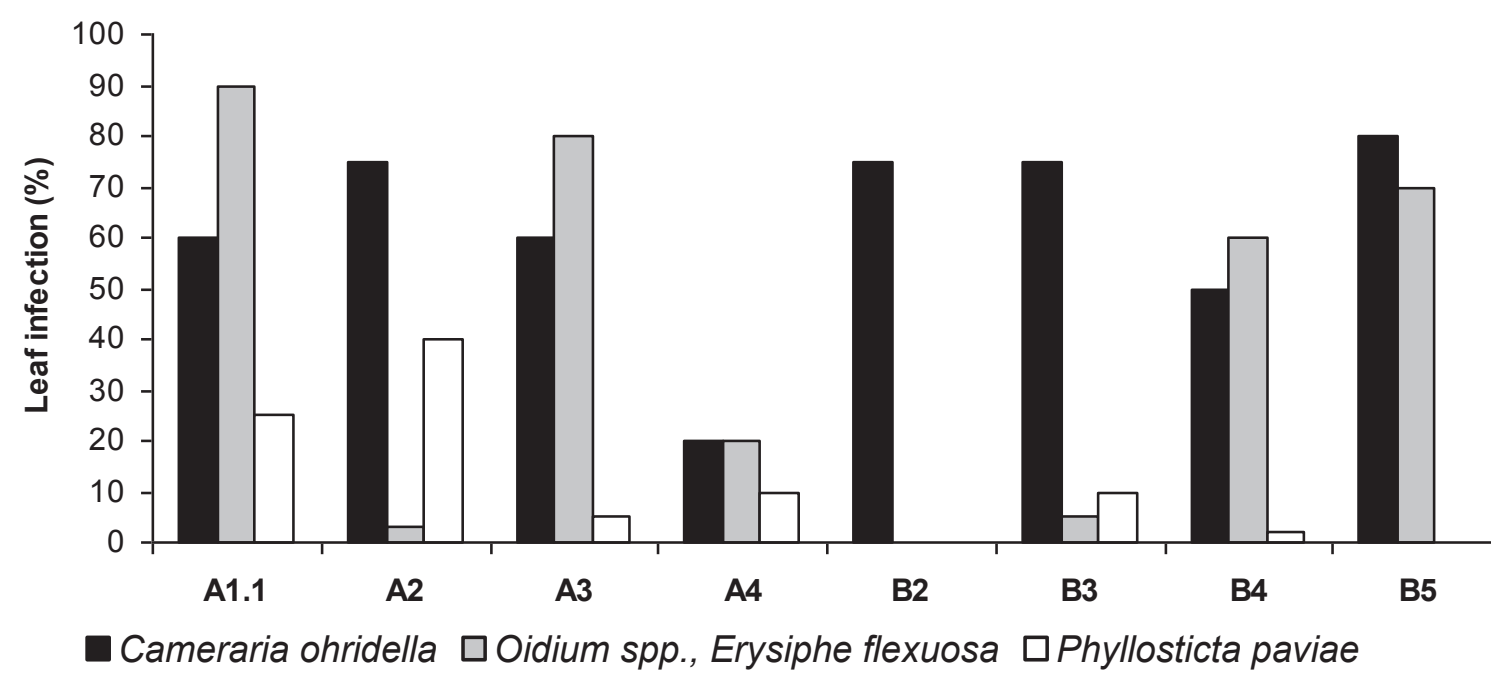

Figure 3. Damage percentage of the leaves of white horse chestnut trees by the pests and pathogens examined in the study at selected localities with white horse chestnut $A$. hippocastanum throughout the vegetative season (A - localities along roads, $\mathrm{B}$ - plantings in parks)

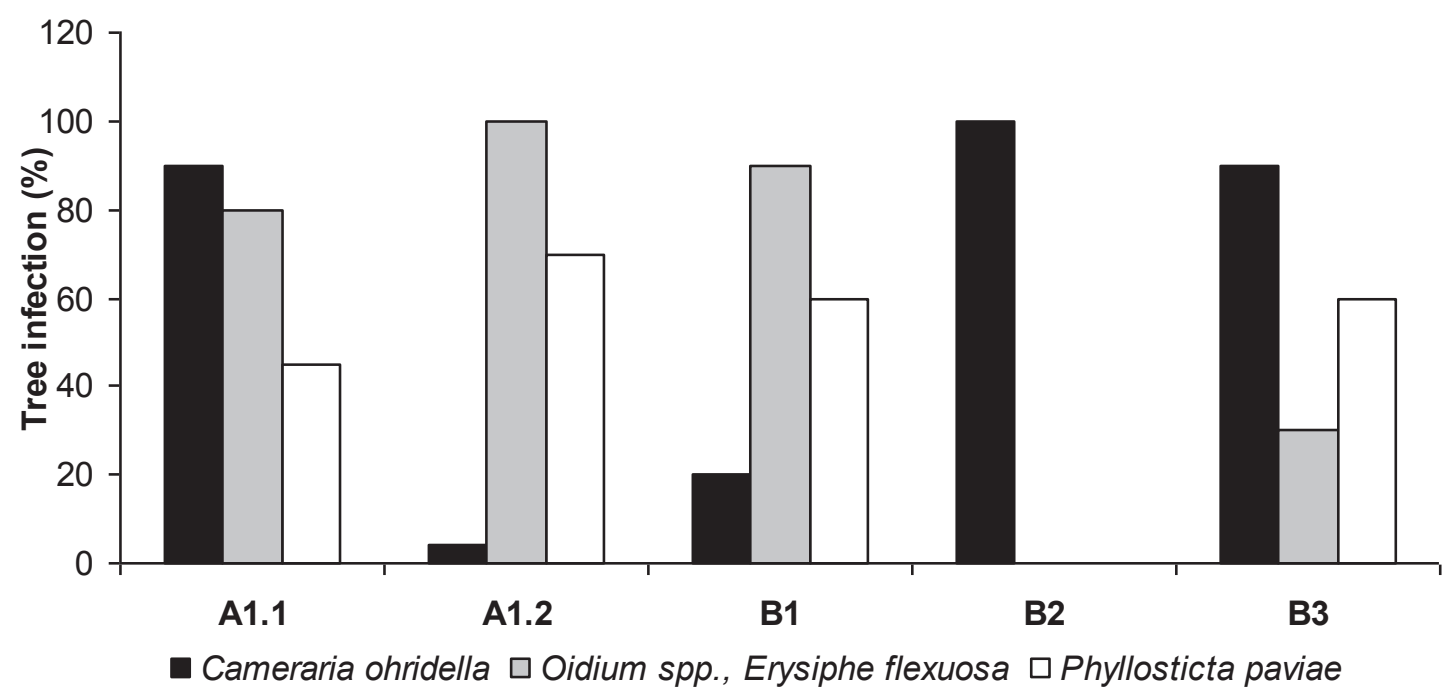

Figure 4. Percentage infection of tree crowns of white horse chestnut $A$. hippocastanum and red horse chestnut $A$. $\times$ carnea at selected localities (A - localities along roads, B - plantings in parks) by pathogens and pests (percentage contribution of infected leaves in relation to all the leaves in the crown) 


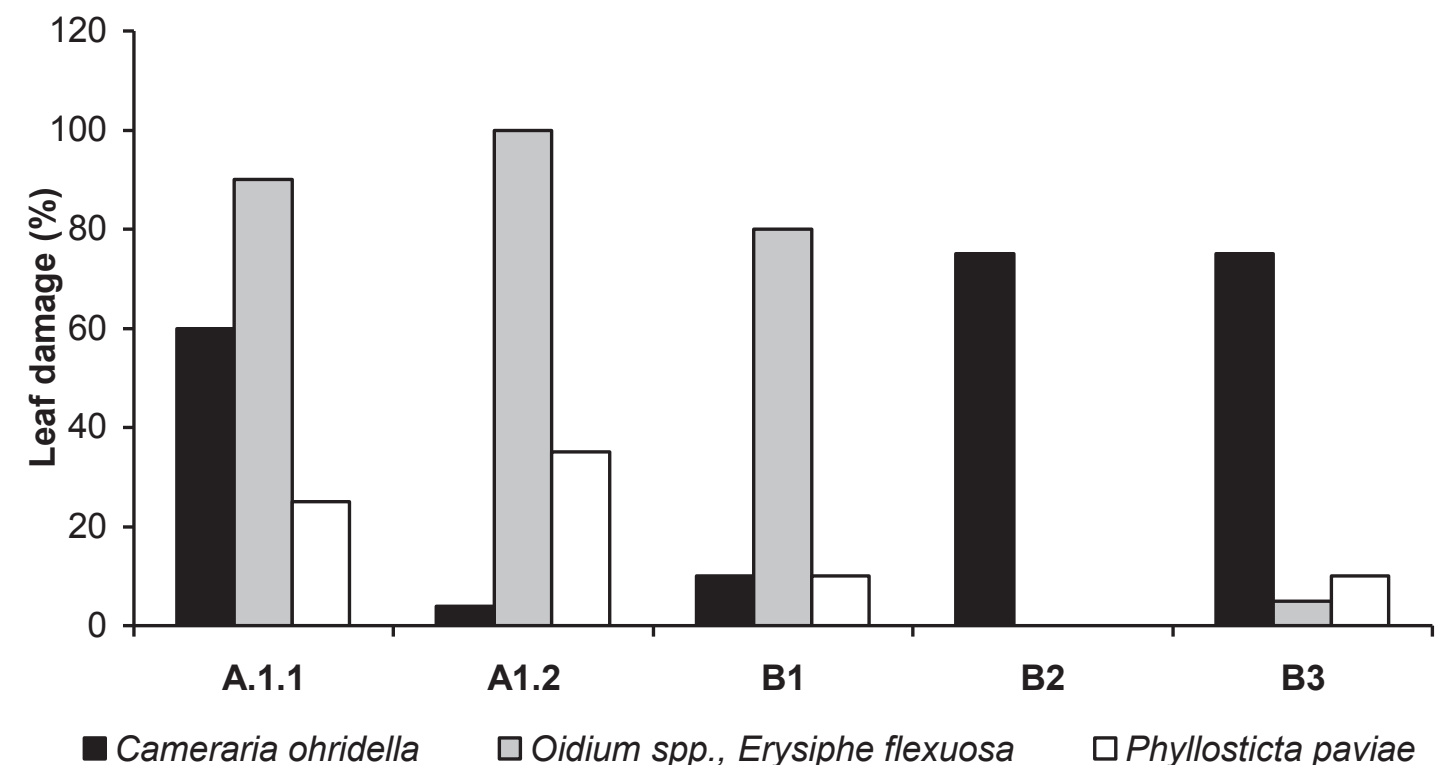

Figure 5. Percentage damage of the leaves of white horse chestnut $A$. hippocastanum and red horse chestnut $A$. $\times$ carnea by the pests and pathogens examined in this study at selected localities with white horse chestnut trees throughout the vegetative season (A - localities along roads, B - plantings in parks)

access to water and decrease a supply of new mineral nutrients also impact on the course of disease in urban conditions (Komosa \& Roszyk, 2006; Oleksyn et al., 2007; Breś, 2008; Łukasiewicz, 2011a, b, c , 2012a, b; Suchocka, 2011; Gołąbek et al., 2014).

Increased susceptibility to infection by pathogens and pests is observed in horse chestnut trees planted near roads and pavements (Łukasiewicz, 2011c). Differences in leaf colonization in horse chestnut trees by causal agents of powdery mildew occurring even within individual localities were also observed by Werner et al. (2012) and Snieškienė et al. (2011). This is most likely caused by divergent resistance levels of individual trees to pathogens. Oszmiański et al. (2015) attribute varied resistance of horse chestnut trees to pathogens and pests to the content of phenol compounds in the tissue of individual hosts.

\subsection{Foliar content of assimilation pigments}

The content of photosynthetic pigments, mainly chlorophyll, in assimilation organs is a vital trait that affects the intensity of binding carbon dioxide by the appropriate amount of their active forms in the total assimilation surface of a plant (Hall \& Rao, 1999; Pilarski, 2000). The determination of assimilation pigments in plant tissue is of scientific and practical importance as it can be an indication of the intensity of photosynthesis and biomass production, can reflect the accumulation of nutrients, mainly nitrogen, in plants and can be an indicator of the physiological condition of plants, for instance plants under stress (Richardson et al., 2002). Both abiotic and biotic environmental factors, including plant infection by diseases and pests, influence the content of assimilation pigments in plant tissue. Trees in the urban environment are exposed to a complex set of stressors.

An analysis of foliar content of assimilation pigments of white horse chestnut trees at localities along roads and in parks in Szczecin shows that it varied for all the pigments analyzed and depended on the location of the site and the sampling date. The lowest content of chlorophyll a, significantly lower than that in the leaves of plants derived from localities A2, A1.1, A3 and B4, was recorded in the leaves of horse chestnut trees at localities B2, B3 and A4 on sampling date I. The lowest content of chlorophyll a was detected in the leaves of trees at locality B4 on sampling date II. The content of chlorophyll a in the leaves of horse chestnut trees growing at the remaining park localities (B2, B3 and B5) was higher than that in the leaves at localities along streets. The lowest content of chlorophyll a was recorded in the leaves of trees at localities B3, A1.1, B2 and B5 on sampling date III and in the leaves of trees at localities B3 and A4 on sampling date IV (Table 3).

The highest foliar content of chlorophyll $b$ was detected on sampling dates I and II for trees at localities A3, B4 and A1.1 as well as B5 and B2, respectively. The mean foliar content of chlorophyll b was lower on the last sam- 
pling date than those recorded on previous sampling dates. A significant variation of chlorophyll $b$ content depending on the locality was not detected (Table 4).

The highest content of total foliar chlorophyll in white horse chestnut trees on sampling date I was recorded for trees at locality A1.1 and the lowest for trees at localities B2, B3, B5 and A4. The lowest content of total chlorophyll on sampling dates II and III was recorded in the leaves of horse chestnut trees at B4 as well as B3, A1.1, B2 and $\mathrm{B} 5$, respectively. It was the lowest in the leaves of trees at localities B3 and A4 on sampling date IV (Table 5).

Carotenoids are important assimilation pigments and supplement spectrally the absorption range of photosynthesis as photosynthetic antennae. They also act as photoprotectors, take part in the dissipation of excess excited state energy in the xanthophyll Guignardia blotch of buckeyes and horse chestnut cycle, protect photosystems from damage, remove free oxygen radicals and influence the smoothness and structure of photosynthetic membranes (Gieczewska, 2015). The greatest foliar content of carotenoids in white horse chestnuts trees, both along roads and in parks, was recorded at localities A1.1, B5, A3 and B5, for successive sampling dates (Table 6).

A comparison of foliar content of assimilation pigments in white and red horse chestnut trees growing at localities along roads (A1.1 and A1.2) and in parks (B1 and B2) shows that the greatest content of chlorophyll a and total chlorophyll was recorded in the leaves of red horse chestnut trees growing at a park locality on all the sampling dates. A similarly high content of chlorophyll a was detected on sampling date I in the leaves of both species of horse chestnut trees at a roadside locality. The content of chlorophyll a was higher in the leaves of white horse chestnut trees than in those of red horse chestnut trees at a roadside locality on sampling date II (Table 7). A higher content of chlorophyll $b$ in the leaves of red horse chestnut trees was detected at a park locality on sampling dates I, II and IV. A higher content of chlorophyll b and total chlorophyll in trees growing along roads was recorded in white horse chestnut trees on sampling dates II and III. For trees growing in parks, the content of total chlorophyll was higher in red horse chestnut trees on all sampling dates (Tables 8 and 9).

The highest foliar content of carotenoids was recorded for white horse chestnut trees at locality A on sampling date I and for red horse chestnut trees at locality B on sampling dates II and III. For trees growing along roads, the content of carotenoids was higher in white horse chestnut trees on all the sampling dates. The content of carotenoids was higher in red horse chestnut trees at park localities on sampling dates II and III (Table 10).

Foliar content of these assimilation pigments in white horse chestnut trees varied and was dependent both on the site's location and the sampling date. In white horse chestnut trees, the lowest chlorophyll content was detected in the leaves of trees in park localities on successive sampling dates. This was related to a higher rate and greater degree of infection of leaves by pathogens and pests. The greatest content of carotenoids in the leaves of white horse chestnut trees was recorded both in trees growing at localities along streets and in parks depending on the sampling date. For trees in park localities, the content of total chlorophyll was higher in red horse chestnut trees on all the sampling dates.

Table 3. The content of chlorophyll a in the leaves of white horse chestnut trees $\left[\mathrm{mg} \cdot \mathrm{g}^{-1} \mathrm{f} . \mathrm{m}\right.$.] depending on the locality (notation of localities and tree species as in Table 1)

\begin{tabular}{|c|c|c|c|c|c|}
\hline Locality No. & Date I & Date II & Date III & Date IV & Mean \\
\hline A1.1 & $2.90^{*} \mathrm{~d}$ & $2.08 \mathrm{~b}$ & $1.78 \mathrm{a}$ & n.d. $^{* *}$ & 1.98 \\
\hline A2 & $2.54 \mathrm{bc}$ & $2.41 \mathrm{c}$ & $2.86 \mathrm{~cd}$ & $1.97 \mathrm{~b}$ & 2.44 \\
\hline A3 & $2.90 \mathrm{~d}$ & $2.45 \mathrm{c}$ & $3.13 \mathrm{~d}$ & $2.30 \mathrm{c}$ & 2.69 \\
\hline A4 & $2.03 \mathrm{a}$ & $2.48 \mathrm{c}$ & $2.43 \mathrm{~b}$ & $1.68 \mathrm{a}$ & 2.15 \\
\hline B2 & $1.90 \mathrm{a}$ & $2.66 \mathrm{~d}$ & $1.99 \mathrm{a}$ & $2.01 \mathrm{~b}$ & 2.14 \\
\hline B3 & $2.00 \mathrm{a}$ & $2.76 \mathrm{de}$ & $1.76 \mathrm{a}$ & $1.57 \mathrm{a}$ & 2.02 \\
\hline B4 & $2.70 \mathrm{~cd}$ & $1.45 \mathrm{a}$ & $2.63 \mathrm{bc}$ & $2.47 \mathrm{~cd}$ & 2.31 \\
\hline B5 & $2.20 \mathrm{ab}$ & $2.89 \mathrm{e}$ & $2.02 \mathrm{a}$ & $2.65 \mathrm{~d}$ & 2.44 \\
\hline Mean & 2.40 & 2.40 & 2.32 & 2.09 & 2.30 \\
\hline
\end{tabular}

$*$ - means denoted with the same letters do not differ significantly at significance level $\alpha=0.05 ; * *-$ not determined 
Table 4. The content of chlorophyll $\mathrm{b}$ in the leaves of white horse chestnut trees $\left[\mathrm{mg} \cdot \mathrm{g}^{-1} \mathrm{f} . \mathrm{m}\right.$.] depending on the locality

\begin{tabular}{|c|c|c|c|c|c|}
\hline Locality No. & Date I & Date II & Date III & Date IV & Mean \\
\hline A1.1 & $1.34 \mathrm{c}$ & $0.99 \mathrm{a}$ & $0.81 \mathrm{a}$ & 1.05 \\
\hline A2 & $1.00 \mathrm{~b}$ & $1.01 \mathrm{a}$ & $1.30 \mathrm{~d}$ & $0.89 \mathrm{a}$ & 1.05 \\
\hline A3 & $1.25 \mathrm{c}$ & $1.19 \mathrm{a}$ & $1.35 \mathrm{~d}$ & $1.04 \mathrm{a}$ & 1.21 \\
\hline A4 & $1.00 \mathrm{~b}$ & $1.23 \mathrm{a}$ & $1.04 \mathrm{bc}$ & $0.70 \mathrm{a}$ & 0.99 \\
\hline B2 & $0.80 \mathrm{a}$ & $1.30 \mathrm{~b}$ & $0.83 \mathrm{a}$ & $0.88 \mathrm{a}$ & 0.95 \\
\hline B3 & $0.87 \mathrm{ab}$ & $0.65 \mathrm{a}$ & $0.74 \mathrm{a}$ & $0.68 \mathrm{a}$ & 0.73 \\
\hline B4 & $1.29 \mathrm{c}$ & $0.67 \mathrm{a}$ & $1.20 \mathrm{~cd}$ & $0.92 \mathrm{a}$ & 1.02 \\
\hline B5 & $0.94 \mathrm{ab}$ & $1.28 \mathrm{~b}$ & $0.88 \mathrm{ab}$ & $0.76 \mathrm{a}$ & 0.96 \\
\hline Mean & 1.06 & 1.04 & 1.02 & 0.84 & \\
\hline
\end{tabular}

Table 5. The content of total chlorophyll in the leaves of white horse chestnut trees $\left[\mathrm{mg} \cdot \mathrm{g}^{-1} \mathrm{f} . \mathrm{m}.\right]$ depending on the locality

\begin{tabular}{|c|c|c|c|c|c|}
\hline Locality No. & Date I & Date II & Date III & Date IV & Mean \\
\hline A1.1 & $2.86 \mathrm{~d}$ & $3.08 \mathrm{~b}$ & $2.59 \mathrm{a}$ & n.d. & 2.84 \\
\hline A2 & $1.84 \mathrm{~b}$ & $3.42 \mathrm{bc}$ & $4.16 \mathrm{~cd}$ & $2.86 \mathrm{~b}$ & 3.07 \\
\hline A3 & $2.51 \mathrm{c}$ & $3.64 \mathrm{bcd}$ & $4.48 \mathrm{~d}$ & $3.35 \mathrm{~cd}$ & 3.49 \\
\hline A4 & $1.47 \mathrm{a}$ & $3.71 \mathrm{bcd}$ & $3.46 \mathrm{~b}$ & $2.38 \mathrm{a}$ & 2.75 \\
\hline B2 & $1.29 \mathrm{a}$ & $3.96 \mathrm{~cd}$ & $2.82 \mathrm{a}$ & $2.89 \mathrm{bc}$ & 2.36 \\
\hline B3 & $1.40 \mathrm{a}$ & $3.41 \mathrm{bc}$ & $2.50 \mathrm{a}$ & $2.25 \mathrm{a}$ & 2.39 \\
\hline B4 & $2.26 \mathrm{c}$ & $2.12 \mathrm{a}$ & $3.83 \mathrm{bc}$ & $3.39 \mathrm{~d}$ & 2,90 \\
\hline B5 & $1.44 \mathrm{a}$ & $4.17 \mathrm{~d}$ & $2.90 \mathrm{a}$ & $3.41 \mathrm{~d}$ & 2.98 \\
\hline Mean & 1.88 & 3.44 & 3.34 & 2.94 & 2.90 \\
\hline
\end{tabular}

Table 6. The content of carotenoids in the leaves of white horse chestnut trees $\left[\mathrm{mg} \cdot \mathrm{g}^{-1} \mathrm{f} . \mathrm{m}\right.$.] depending on the locality

\begin{tabular}{|c|c|c|c|c|c|}
\hline Locality No. & Date I & Date II & Date III & Date IV & Mean \\
\hline A1.1 & $2.86 \mathrm{~d}$ & $1.58 \mathrm{a}$ & $1.30 \mathrm{a}$ & n.d. & 1.91 \\
\hline A2 & $1.84 \mathrm{~b}$ & $1.86 \mathrm{bc}$ & $2.69 \mathrm{~d}$ & $1.34 \mathrm{~b}$ & 1.93 \\
\hline A3 & $2.51 \mathrm{c}$ & $1.75 \mathrm{~b}$ & $3.16 \mathrm{e}$ & $1.64 \mathrm{c}$ & 2.26 \\
\hline A4 & $1.47 \mathrm{a}$ & $1.94 \mathrm{c}$ & $1.78 \mathrm{bc}$ & $1.09 \mathrm{a}$ & 1.57 \\
\hline B2 & $1.29 \mathrm{a}$ & $2.15 \mathrm{~d}$ & $1.36 \mathrm{ab}$ & $1.34 \mathrm{~b}$ & 1.53 \\
\hline B3 & $1.40 \mathrm{a}$ & $2.19 \mathrm{~d}$ & $1.20 \mathrm{a}$ & $1.08 \mathrm{a}$ & 1.47 \\
\hline B4 & $2.26 \mathrm{c}$ & $1.74 \mathrm{~b}$ & $2.17 \mathrm{c}$ & $1.62 \mathrm{c}$ & 1.95 \\
\hline B5 & $1.44 \mathrm{a}$ & $2.40 \mathrm{e}$ & $1.42 \mathrm{ab}$ & $1.90 \mathrm{~d}$ & 1.79 \\
\hline Mean & 1.88 & 1.95 & 1.88 & 1.43 & \\
\hline
\end{tabular}


Table 7. The content of chlorophyll a $\left[\mathrm{mg} \cdot \mathrm{g}^{-1} \mathrm{f} . \mathrm{m}\right.$.] in the leaves of white horse chestnut trees and red horse chestnut trees

\begin{tabular}{|c|c|c|c|c|c|}
\hline $\begin{array}{c}\text { Locality } \\
\text { and tree species } \\
\text { No. }\end{array}$ & Date I & Date II & Date III & Date IV & Mean \\
\hline A1.1 & $2.90 \mathrm{~b}$ & $2.08 \mathrm{~b}$ & $2.13 \mathrm{a}$ & n.d. & 2.37 \\
\hline A1.2 & $2.80 \mathrm{~b}$ & $1.56 \mathrm{a}$ & $1.66 \mathrm{a}$ & $1.99 \mathrm{a}$ & 2.00 \\
\hline B2 & $1.90 \mathrm{a}$ & $2.66 \mathrm{c}$ & $2.00 \mathrm{a}$ & $2.01 \mathrm{a}$ & 2.14 \\
\hline B1 & $2.88 \mathrm{~b}$ & $3.01 \mathrm{~d}$ & $2.80 \mathrm{~b}$ & $2.39 \mathrm{~b}$ & 2.77 \\
\hline Mean & 2.62 & 2.33 & 2.15 & 2.13 & \\
\hline
\end{tabular}

Table 8. The content of chlorophyll $\mathrm{b}\left[\mathrm{mg} \cdot \mathrm{g}^{-1} \mathrm{f} . \mathrm{m}\right.$.] in the leaves of white horse chestnut trees and red horse chestnut trees

\begin{tabular}{|c|c|c|c|c|c|}
\hline $\begin{array}{c}\text { Locality } \\
\text { and tree species } \\
\text { No. }\end{array}$ & Date I & Date II & Date III & Date IV & Mean \\
\hline A1.1 & $1.34 \mathrm{~b}$ & $1.00 \mathrm{~b}$ & $0.98 \mathrm{~b}$ & n.d. & 1.11 \\
\hline A1.2 & $1.22 \mathrm{~b}$ & $0.73 \mathrm{a}$ & $0.74 \mathrm{a}$ & $0.99 \mathrm{a}$ & 0.92 \\
\hline B2 & $0.80 \mathrm{a}$ & $1.30 \mathrm{c}$ & $0.83 \mathrm{ab}$ & $0.88 \mathrm{a}$ & 0.95 \\
\hline B1 & $1.15 \mathrm{~b}$ & $1.23 \mathrm{bc}$ & $1.21 \mathrm{c}$ & $1.04 \mathrm{~b}$ & 1.16 \\
\hline Mean & 1.13 & 1.06 & 0.94 & 0.97 & \\
\hline
\end{tabular}

Table 9. The content of total chlorophyll $\left[\mathrm{mg} \cdot \mathrm{g}^{-1} \mathrm{f} . \mathrm{m}\right.$.] in the leaves of white horse chestnut trees and red horse chestnut trees

\begin{tabular}{|c|c|c|c|c|c|}
\hline $\begin{array}{c}\text { Locality } \\
\text { and tree species } \\
\text { No. }\end{array}$ & Date I & Date II & Date III & Date IV & Mean \\
\hline $\mathrm{A} 1.1$ & $4.24 \mathrm{~b}$ & $3.08 \mathrm{~b}$ & $3.11 \mathrm{~b}$ & n.d. & 3.48 \\
\hline $\mathrm{A} 1.2$ & $4.02 \mathrm{~b}$ & $2.29 \mathrm{a}$ & $2.40 \mathrm{a}$ & $2.98 \mathrm{a}$ & 2.92 \\
\hline $\mathrm{B} 2$ & $2.70 \mathrm{a}$ & $3.96 \mathrm{c}$ & $2.83 \mathrm{ab}$ & $2.89 \mathrm{a}$ & 3.09 \\
\hline $\mathrm{B} 1$ & $4.03 \mathrm{~b}$ & $4.24 \mathrm{~d}$ & $4.01 \mathrm{c}$ & $3.43 \mathrm{~b}$ & 3.93 \\
\hline Mean & 3.74 & 2.97 & 3.09 & 3.10 & \\
\hline
\end{tabular}

Table 10. The content of carotenoids [mg $\mathrm{g}^{-1} \mathrm{f} . \mathrm{m}$.] in the leaves of white horse chestnut trees and red horse chestnut trees

\begin{tabular}{|c|c|c|c|c|c|}
\hline $\begin{array}{c}\text { Locality } \\
\text { and tree species } \\
\text { No. }\end{array}$ & Date I & Date II & Date III & Date IV & Mean \\
\hline A1.1 & $2.86 \mathrm{c}$ & $1.58 \mathrm{~b}$ & $1.68 \mathrm{~b}$ & n. d. & 2.04 \\
\hline $\mathrm{A} 1.2$ & $2.24 \mathrm{~b}$ & $1.06 \mathrm{a}$ & $1.10 \mathrm{a}$ & $1.45 \mathrm{a}$ & 1.46 \\
\hline $\mathrm{B} 2$ & $1.29 \mathrm{a}$ & $2.15 \mathrm{c}$ & $1.36 \mathrm{ab}$ & $1.34 \mathrm{a}$ & 1.20 \\
\hline B1 & $2.63 \mathrm{ab}$ & $2.74 \mathrm{~d}$ & $2.37 \mathrm{c}$ & $1.47 \mathrm{a}$ & 2.30 \\
\hline Mean & 2.25 & 1.88 & 1.63 & 1.42 & \\
\hline
\end{tabular}




\section{References}

Arnon D.J., Allen M.B. \& Whatley F., 1956, Photosynthesis by isolated chloroplast, Biochimica et Biophysica Acta 20: 449-461.

Baranowski T. Parus A. \& Fajfer B, 2002, Występowanie szrotówka kasztanowcowiaczka na kasztanowcach [Occurrence of the horse-chestnut leaf miner on the common horse chestnut], Progress in Plant Protection/ Postępy w Ochronie Roślin 42(2): 654-657.

Bichta P. \& Kozakiewicz P., 2002, Kasztanowce wołają o ratunek [Horse chestnuts call for rescue], Przyroda Polska 10(2): 36-37.

Bielawska A., Czubińska M., Górska M. \& Wolska K., 1964, Obserwacje fenologiczne nad drzewami i krzewami aklimatyzowanymi w Ogrodzie Botanicznym Uniwersytetu im. Adama Mickiewicza w Poznaniu w latach 1957-1961 [Phenological observations of trees and shrubs in the Adam Mickiewicz University Botanical Garden in Poznań in 1957-1961], Pr. Kom. Biol. PTPN 28(3): 1-108.

Breś W., 2008, Czynniki antropopresji powodujące zamieranie drzew w krajobrazie miejskim, [Anthropopressure factors causing trees to die off in urban landscape], Nauka Przyroda Technologie 2(4): 1-8. [http://www. npt.up-poznan.net/tom2/zeszyt4/art_31.pdf].

Bystrowski C., Celmer-Warda K. \& Karwacki G., 2008, Wpływ stanowiska kasztanowca (Aesculus hippocastanum L.) na występowanie i liczebność parazytoidów szrotówka kasztanowcowiaczka (Cameraria ohridella Deschka \& Dimić) w centralnej Polsce, [Effects of horse chestnut (Aesculus hippocastanum L.) site on horse chestnut leafminer (Cameraria ohridella Deschka \& Dimić) parazytoids appearance and number in Central Poland], Leśne Prace Badawcze (Forest Research Papers) 69 (1): 49-55.

Chylarecki H. \& Straus H., 1968, Wyniki dziesięcioletnich obserwacji fenologicznych nad drzewami i krzewami w Arboretum Kórnickim [The results of ten-year phenological observations of trees and shrubs in Kórnik Arboretum], Arboretum Kórnickie 13: 37-120.

Dudzik S., 2002, Nowy szkodnik kasztanowców [New pest of the horse chestnut], Wiadomości Rolnicze 11: 17.

Gieczewska K., 2015, "Napędzanie światłem" - od fotosyntezy do fotoogniwa [Driven by light - From photosynthesis to photocell unit], Kosmos 64(3): 387-399.

Girardoz S., Kenis M. \& Quicke L.J., 2006, Recruitment of native parasitoids by an exotic leaf miner, Cameraria ohridella: host-parasitoid synchronization and influence of the environment, Agricultural and Forest Entomology 8: 49-56.

Gołąbek E., Sławiński J. \& Jasińska O., 2014, Stan zdrowotny drzew i jakość siedliska na terenie miasta
Oświęcim [The state of health of the trees and the quality of habitat in the city of Oświęcim], Inżynieria Ekologiczna 38: 181-190.

Grabenweger G., 2003, Parasitism of different larval stages of Cameraria ohridella, Biocontrol 48: 671-684.

Grabenweger G., Avtzis N., Girardoz S., Hrasovec B., Tomom R. \& Kenis M., 2005, Parasitism of Cameraria ohridella (Lepidoptera: Gracillariidae) in natural and artificial horsechesnut stands in the Balkans, Agricultural and Forest Entomology 7: 307-318.

Hager A. \& Mayer-Berthenrath T., 1966, Die Isolierung und quantitative Bestimung der Carotenoide und Chlorophyll von Blatern, Algen und isolierten Chloroplasten mit Hilfe Dunnschichtchromatographischer Methoden, Planta, Berlin 69: 198-217.

Hall D. \& Rao K.K, 1999, Fotosynteza [Photosynthesis], WNT, Warszawa.

Komosa A., Roszyk J., 2006, Przyczyny i zapobieganie zamieraniu dębów rogalińskich, [The reasons and prevention of the Rogalin oaks dying], Acta Agrophysica 7(4): 937-946.

Kosibowicz M., 2005, Szrotówek kasztanowcowiaczek Cameraria ohridella Deschka \& Dimic (Lepidoptera, Gracillariidae), nowy inwazyjny szkodnik kasztanowca białego Aesculus hippocastanum L. w Polsce - biologia i metody zwalczania [The horse chestnut leaf miner Cameraria ohridella Deschka \& Dimić (Lepidoptera, Gracillariidae), as a New invasive pest of Aesculus hippocastanum L. in Poland - Biology and control methods], Leśne Prace Badawcze 2: 121-132.

Krotoska T., 1961, Obserwacje fenologiczne w QuercetoCarpinetum medioeuropaeum Tx. 1936 i w Querceto-Potentilletum albae Libbert 1933 w Wielkopolskim Parku Narodowym, [Phenological observations in Querceto-Carpinetum medioeuropaeum Tx. 1936 and Querceto-Potentilletum albae Libbert 1933 in Wielkopolska National Park], Prace Monograficzne PTPN [Monographic series PTPN], Wydz. Mat.-Przyr. 3,6 .

Lichtenthaler H.K. \& Wellburn A.R., 1983, Determination of total carotenoids and chlorophyll a and b of leaf extract in different solvents, Biochemical Society Transactions 11: 591-592.

Łukasiewicz A., 1984, Potrzeba ujednolicenia metodyki fenologicznej w polskich ogrodach botanicznych i arboretach, [Necessity of standarization of phenological methods in Polish Botanical Gardens and arboreta], Wiadomości Botaniczne 28(2): 153-158.

Łukasiewicz S., 2011a, Struktura fizyczna gruntu, zawartość substancji organicznej oraz skład chemiczny gleb w podłożach 21 stanowisk zieleni miejskiej na terenie Poznania. Część I. Struktura fizyczna gruntu [The physical structure of land, the content of organic substances, and chemical composition of soil comprising 
the subsoil of 21 urban greenery locations in the area of Poznań. Part I. Physical structure of land], Badania Fizjograficzne, Seria A, 62: 87-103. [DOI 10.2478/ v10116-011-0007-7].

Łukasiewicz S., 2011b, Struktura fizyczna gruntu, zawartość substancji organicznej oraz skład chemiczny gleb w podłożach 21 stanowisk zieleni miejskiej na terenie Poznania. Część II. Zawartość substancji organicznej w podłożu. Odczyn gleby [The physical structure of land, the content of organic substances, and chemical composition of soil comprising the subsoil of 21 urban greenery locations in the area of Poznań. Part II. Content of organic substances in the soil. Soil $\mathrm{pH}$ values], Badania Fizjograficzne, Seria A Geografia Fizyczna 62: 87-96.

Łukasiewicz S., 2011c, Drzewa i krzewy polecane do obsadzeń ulicznych w miastach (ze szczególnym uwzględnieniem środkowozachodniej Polski) [Trees and shrubs recommended for planting in cities (particularly in Central-Western Poland)], [in:] Rośliny do zadań specjalnych [Plants for special tasks], M.E. Drozdek (ed.), Wydawnictwo PWSZ w Sulechowie, Sulechów: 313-324.

Łukasiewicz S., 2012a, Struktura fizyczna gruntu, zawartość substancji organicznej oraz skład chemiczny gleb w podłożach 21 stanowisk zieleni miejskiej na terenie Poznania. Część III. Zawartość makroelementów: $\mathrm{N}, \mathrm{P}, \mathrm{K}, \mathrm{S}, \mathrm{Ca}$ i Mg [The physical structure of land, the content of organic substances, and chemical composition of soil comprising the subsoil of 21 urban greenery locations in the territory of Poznań. Part III. Amounts of macroelements: N, P, K, S, Ca and Mg], Badania Fizjograficzne, Seria A Geografia Fizyczna 63: 7-47. [DOI 10.2478/v10116-012-0001-8].

Łukasiewicz S., 2012b, Struktura fizyczna gruntu, zawartość substancji organicznej oraz skład chemiczny gleb w podłożach 21 stanowisk zieleni miejskiej na terenie Poznania. Część IV. Zawartość mikroelementów: $\mathrm{Cl}$, Fe, Mn, Zn, Cu, B oraz Na, Pb i Cd. Wskaźnik zasolenia EC [The physical structure of land, the content of organic substances, and chemical composition of soil comprising the subsoil of 21 urban greenery locations in the territory of Poznań. Part IV. Content of microelements: $\mathrm{Cl}, \mathrm{Fe}, \mathrm{Mn}, \mathrm{Zn}, \mathrm{Cu}, \mathrm{B}$ and $\mathrm{Na}, \mathrm{Pb}$, Cd. The "EC" salinity index], Badania Fizjograficzne, Seria A Geografia Fizyczna 63: 49-75. [http://hdl.handle.net/10593/9714].

Łukasiewicz S. \& Oleksyn J., 2007, Zróżnicowanie przestrzenne elementów meteorologicznych i ich wpływ na rozwój kasztanowca zwyczajnego (Aesculus hippocastanum L.) w warunkach miejskich Poznania [Heterogeneity of spatial meteorological traits and their effects on horsechesnut (Aesculus hippocastanum L.) development in urban conditions of Poznań],
Badania Fizjograficzne, Seria A Geografia Fizyczna 58: 47-78.

Madej T., 1971a, Notatki mikologiczne ze Świnoujścia [Mycological notes from Świnoujście], Fragmenta Floristica et Geobotanica 17: 413-424.

Madej T., 1971b, Mikoflora drzew i krzewów ogrodu dendrologicznego w Przelewicach (woj. szczecińskie) [Mycoflora of trees and shrubs in the dendrological garden in Przelewice (Szczecińskie woivodship)], Fragmenta Floristica et Geobotanica 17: 583-600.

Metla Z., Voitkāne S., Sešksena R., Petrova V. \& Jankevica L., 2013, Presence of entomopathogenic fungi and bacteria in Latvian population of horse-chestnut leaf miner Cameraria ohridella, Acta Biologica Universitatis Daugavpiliensis 13(1): 69-76.

Nowak G., 2000, Fenologia wybranych gatunków lipy Tilia na terenie Szczecina [Phenology of selected linden Tilia species in Szczecin], Folia Universitatis Agriculturae Stetinensis 215(86): 75-139.

Oleksyn J., Kloeppel B.D., Łukasiewicz Sz., Karolewski P. \& Reich P.B., 2007, Ecophysiology of horse chestnut (Aesculus hippocastanum L.) in degraded and restored urban sites, Polish Journal of Ecology 55 (2): 245-260.

Oszako T., 2007, Przyczyny masowego zamierania drzewostanów dębowych [Causes of oak stand decline], Sylwan 6: 62-72.

Oszmiański J., Kolniak-Ostek J. \& Biernat A., 2015, The Content of Phenolic Compounds in Leaf Tissues of Aesculus glabra and Aesculus parviflora Walt., Molecules 20: 2176-2189. [DOI:10.3390/molecules2002217].

Percival G.C., Barrow I., Noviss K., Keary I. \& Penningtond P., 2011, The impact of horse chestnut leaf miner (Cameraria ohridella Deschka and Dimic; HCLM) on vitality, growth and reproduction of Aesculus hippocastanum L., Urban Forestry \& Urban Greening 10: $11-17$

Piątek M., 2002, Erysiphe flexuosa, a new for Poland powdery mildew causing disease of Aesculus hippocastanum, Phytopathologia Polonica 24: 67-71.

Pilarski J., 2000, Phytosynthetic activity of stems and leaves of apple, sweet cherry, and plum trees, Folia Horticulturae 12(1): 41-44.

Richardson A.D., Duigan S.P. \& Berlyn G.P., 2002, An evaluation of noninvasive methods to estimate foliar chlorophyll content, New Phytologist 153: 185-194.

Snieškienė V., Baležentienė L. \& Stankevičienė A., 2011, State of horse-chestnut, Aesculus hippocastanum L., in Lithuania: diseases and pest damages, Ekologija 57(2): 62-69.

Soika G., 2004, Poszukiwania skutecznej metody zwalczania szrotówka kasztanowcowiaczka w Europie [Searching for an effective method of horse-chestnut leaf miner control in Europe], Przegląd ekologiczny, Wydanie specjalne 1: 18-19. 
Stachak A., 1968, Fenologia drzew w Puszczy Bukowej pod Szczecinem i w dyluwialnej nadmorskiej części wyspy Wolin [Phenology of trees in Puszcza Bukowa (beech primeval forests) near Szczecin and in the diluvial coastal part of Wolin Island], Rozprawy WSR w Szczecinie 6: 1-71.

Stachak A., 1977, Fenologiczne pory roku na terenie Szczecina (lata 1964-1973) [Phenological seasons in Szczecin (1964-1973)], Zeszyty Naukowe AR w Szczecinie 61: 291-300.

Suchocka M., 2011, Wpływ biotycznych warunków siedliskowych na stan drzew na terenach budowy oraz po zakończeniu inwestycji [The impast of biotic environment conditions on the vitality of trees on construction sites and after completion of construction process], Człowiek i Środowisko 35(3-4): 19-34.
Werner M., Irzykowska L. \& Karolewski Z., 2012, The occurrence and harmfulness of Erysiphe flexuosa and Cameraria ohridella on Aesculus spp., Phytopathologia 65: 5-11.

Wiech K., 2003, Przybysz z Macedonii [A newcomer from Macedonia], Drzewa, Krzewy, Park [Trees, Shrubs, The Park] 9: 11-12.

Zaraś-Januszkiewicz E.M., 2004, Szkodniki kasztanowców (cz.1) [Pests of horse chestnuts (Part I)], Przyroda Polska 1: 7.

Zimmermannová-Pastirčáková K., Adamska I., Błaszkowski J., Bolay A. \& Braun U., 2002, Epidemic spread of Erysiphe flexuosa (North American powdery mildew of horse-chestnut) in Europe, Schlechtendalia 8: $39-45$. 